\title{
Effect of Fumagillin treatment on sea bass Dicentrarchus labrax parasitized by Sphaerospora testicularis (Myxosporea: Bivalvulida)
}

\author{
A. Sitjà-Bobadilla, P. Alvarez-Pellitero \\ Instituto de Acuicultura de Torre de la Sal (C.S.I.C.), Ribera de Cabanes, E-12595 Torre de la Sal, Castellón, Spain
}

\begin{abstract}
The antibiotic Fumidil-B was tested at a dosage of $0.1 \%$ Fumagillin against sea bass Dicentrarchus labrax L. testicular sphaerosporosis in 2 experiments. In Expt 1, fish with naturally acquired advanced sphaerosporosis were treated for $8 \mathrm{wk}$, whereas in Expt 2, fish experimentally inoculated with Sphaerospora testicularis were medicated for $44 \mathrm{~d}$ (short treatment, ST) and $91 \mathrm{~d}$ (long treatment, LT). Toxic effects consisting of loss of appetite and weight and significant decrease of hemoglobin, hematocrit and red blood cell counts appeared in treated fish in both Expt 1 and LT Expt 2. Efficacy of the drug was not apparent until the following spawning season in Expt 1, whereas in Expt 2 only the data concerning drug toxicity could be evaluated.
\end{abstract}

\section{INTRODUCTION}

Myxosporoses were considered non-treatable fish diseases for a long time, and prophylactic measures were the only way to fight against important economic losses. Nevertheless, in the last decade several drugs have been assayed against myxosporeans, such as Proguanil and Clamoxyquin (Alderman 1986), Toltrazuril (Mehlhorn et al. 1988, Schmahl et al. 1989, Yokoyama et al. 1990) and Fumagillin. The latter is an antibiotic isolated from the fungus Aspergillus fumigatus, with a low antibiotic and antifungic action but with a high antibacteriophagic (Mills 1955) and amebicide (McCowen et al. 1951, Killough et al. 1952) activity. First trials were performed against honey bee nosemiasis (Katznelson \& Jamieson 1952, Bailey 1953) and, later they were extended to other microsporean diseases of insects (Lewis \& Lynch 1970, Lynch \& Lewis 1971, Liu 1973) and mammals (Shadduck 1980). Fumidil-B (the bicyclohexyl amine salt of Fumagillin acid) has been successfully used against fish microsporean infections (Takahashi \& Egusa 1976, Kano \& Fukui 1982, Kano et al. 1982, Hedrick et al. 1991).
Recently, experimental assays have shown the potential use of this drug against several myxosporeans such as Sphaerospora renicola in carp (Molnár et al. 1987), PKX in salmonids (Hedrick et al. 1988), Myxidium giardi in European eels (Székely et al. 1988), Hoferellus carassi in goldfish (Yokoyama et al. 1990) and Myxobolus cerebralis in salmonids (ElMatbouli \& Hoffman 1991). Sphaerospora testicularis has been described as an important parasite of cultured sea bass, which destroys testicular tissue and greatly reduces the fecundity of males (Sitjà-Bobadilla \& Alvarez-Pellitero 1990). In the present work, data on the effect of Fumidil-B treatment upon this testicular sphaerosporosis, and its possible side effects on the host are reported.

\section{MATERIALS AND METHODS}

Expt 1. Fish: Mature male sea bass Dicentrarchus labrax L. naturally infected by Sphaerospora testicularis, were obtained from the Instituto de Acuicultura de Torre la Sal (IATS) facilities. They were reared in running sea water ( $3.78 \%$ salinity) at natural tempera- 
ture and photoperiod. Mean weight of fish at the start of the experiment was $800 \mathrm{~g}$.

Experimental conditions: Specimens were divided into 2 groups of 10 fish each, with a similar average level of infection, and kept in $2000 \mathrm{l}$ tanks. One group was fed on a natural diet consisting of trash fish Boops boops, containing gelatin capsules with Fumidil-B at a dose of $1 \mathrm{~g}$ Fumagillin $\mathrm{kg}^{-1}$ feed. Treatment started on 24 May (= Day 0) and continued for $8 \mathrm{wk}$. The other group received an unmedicated diet. Both groups were fed at $1.5 \%$ body weight $\mathrm{d}^{-1}$.

Detection of myxosporean and evaluation of toxicity of treatment: As Sphaerospora testicularis diagnosis can be performed without necropsy (Sitjà-Bobadilla \& Alvarez-Pellitero 1990), fish were periodically anaesthetized with MS-222 (Sigma Chemicals Co., St. Louis, MO, USA) $100 \mathrm{ppm}$, and stripped or cannulated to obtain seminal fluid or testicular tissue respectively, in which $S$. testicularis stages can be detected. In addition, some fish were necropsied at significant sampling times (Days 20, 250, 309 and 371) and their testes processed for histological studies. At the end of the experiment (Day 371) all fish were killed.

In order to monitor the possible toxic effects of the treatment, blood was collected from the caudal vessels of anaesthetized fish on Days -20,20,61, 98, 128 and 155. Haemoglobin concentration (Hb) (Hemocue Photometer, AB Leo Diagnostics, Sweden), haematocrit level ( $\mathrm{HC}$ ) and red blood cell counts (RBC) (Neubauer chamber) were determined. Mean corpuscular haemoglobin concentration (MCHC), mean corpuscular haemoglobin content $(\mathrm{MCH})$ and mean cellular volume (MCV) were also calculated. Hematopoietic organs (head kidney and spleen) and liver from necropsied fish were also processed for histology.

Histological procedure: Tissue portions, fixed with Bouin's solution, were embedded in Paraplast, thin sectioned and stained with hematoxylin-eosin (H\&E). In some cases, 1 to $3 \mu \mathrm{m}$ sections were obtained from material fixed with $2.5 \%$ glutaraldehyde, embedded in Historesin (Leica, Spain), and stained with toluidine blue (TB).

Statistics: Student's $t$-test was used to analyze the influence of the treatment on the studied parameters. Statistical significance was estimated at $\mathrm{p}<0.05$ and $p<0.01$, and is shown in each figure.

Expt 2. Fumagillin treatment was assayed in a second experiment, using sea bass inoculated with sperm containing high quantities of spores and other developmental stages of Sphaerospore testicularis, to assess its utility as a preventive method. As experimental transmission was not achieved (unpubl. data), the provided results deal only with the toxic effects of the treatment.

Fish and experimental conditions: Forty male sea bass (age: $2+y r$ ) free of Sphaerospore testicularis, obtained from an IATS cultured stock, were maintained in 4 experimental tanks (10 fish each) supplied with seawater free of pathogens. Fish from 2 tanks were inoculated intracelomically with stages of $S$. testicularis (20 January = Day 0$)$. One day later, fish began receiving a commercial dry food containing $0.1 \%$ Fumagillin. Treatment was stopped at $44 \mathrm{~d}$ post-injection for 1 medicated tank (short treatment, ST) and at $91 \mathrm{~d}$ postinjection for the other medicated tank (long treatment, LT). Fish from the other 2 tanks were kept as a control group and received an unmedicated diet.

Detection of the myxosporean, evaluation of toxic effects, histological procedure and statistics applied were the same as in Expt 1

\section{RESULTS}

\section{Efficacy of treatment}

All the reported results deal with Expt 1. Fig. 1 shows the evolution of prevalence of infection by Sphaerospore testicularis. During most of the experiment the level of infection in both groups was very similar. Nevertheless, in the last sampling (Day 309), which coincided with the subsequent spawning season after treatment, medicated fish showed a clearly lower prevalence of infection than untreated ones, and most of the treated infected fish presented low intensities of infection and harboured no spores. In addition, treated fish started spermiation 2 mo earlier than untreated ones.

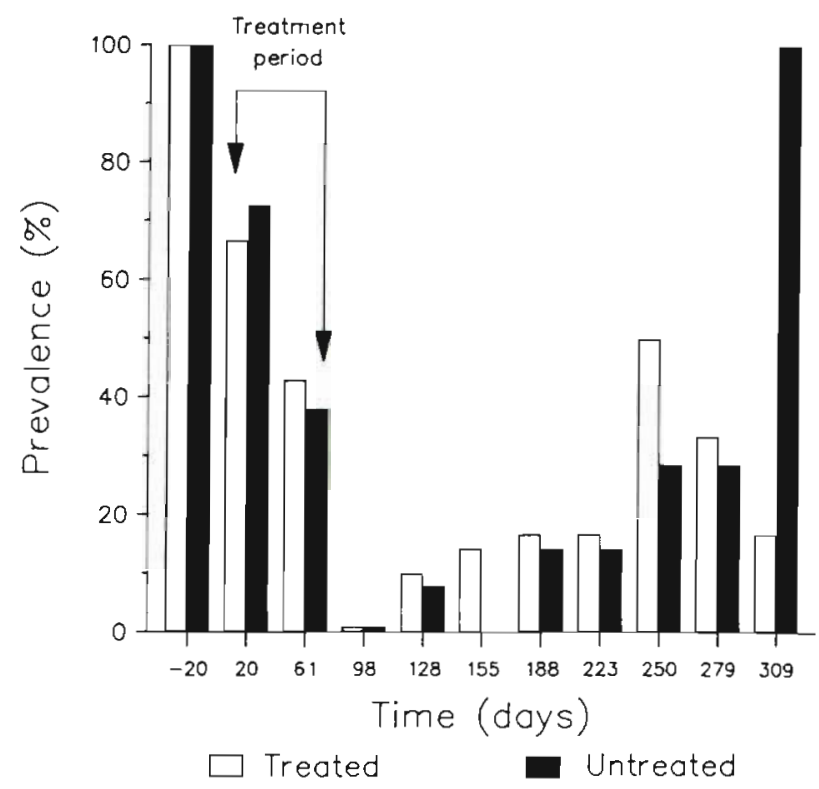

Fig. 1 Sphaerospora testicularis. Evolution of the prevalence of infection in sea bass in Expt 1 
Histological sections of testes showed a similar testicular damage provoked by the sphaerosporid in both groups throughout most of the experiment. However, at Day 371, in the interbreeding period, testes from control fish appeared with extensive gran- ulomatous areas and scarce germinative development (Fig. 2A). In contrast, testes from medicated fish had numerous primary spermatogonia (Fig. 2B). Accordingly, at Day 309, during the spawning season, testes from treated fish showed seminiferous tubules filled
Fig. 2. Sphaerospora testicularis, Dicentrarchus labrax. Paraplast (A\&B; at Day 371 , during the interbreeding season) and Historesin (C\&D; at Day 309, during the spawning season) sections of sea bass testes of Expt 1. (A) Granulomatous view of an untreated fish. (B) Panoramic view of a normal testis with proliferation of spermatogonia from a Fumagillin-medicated fish. (C) Testis with absence of germinative tissue and large areas of necrotic debris, from an untreated male. (D) Testis with spermatozoa from a medicated fish. Stain: (A \& B), H\&E; (C \& D $)$, TB. Scale bars = $100 \mu \mathrm{m}$
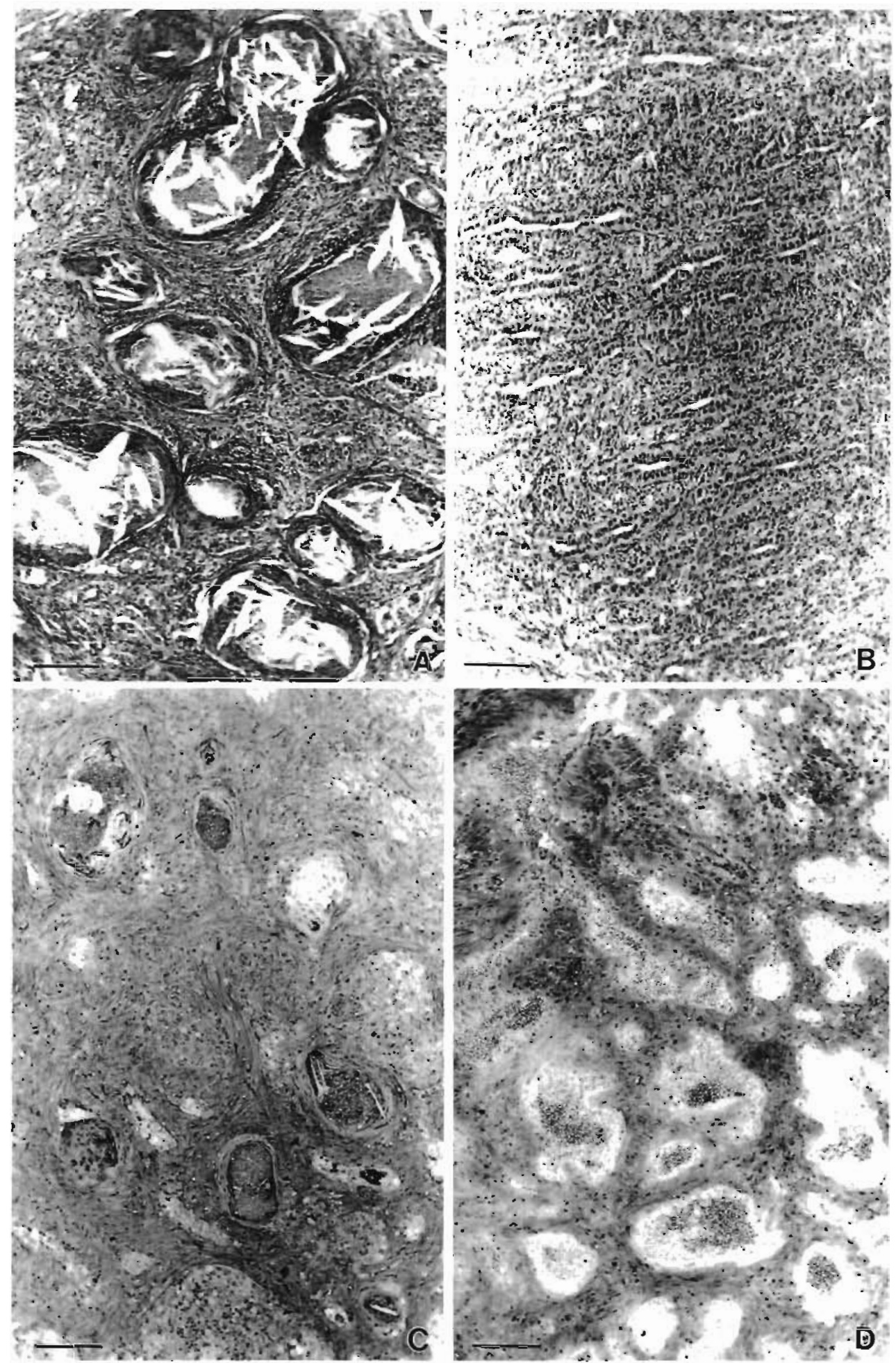


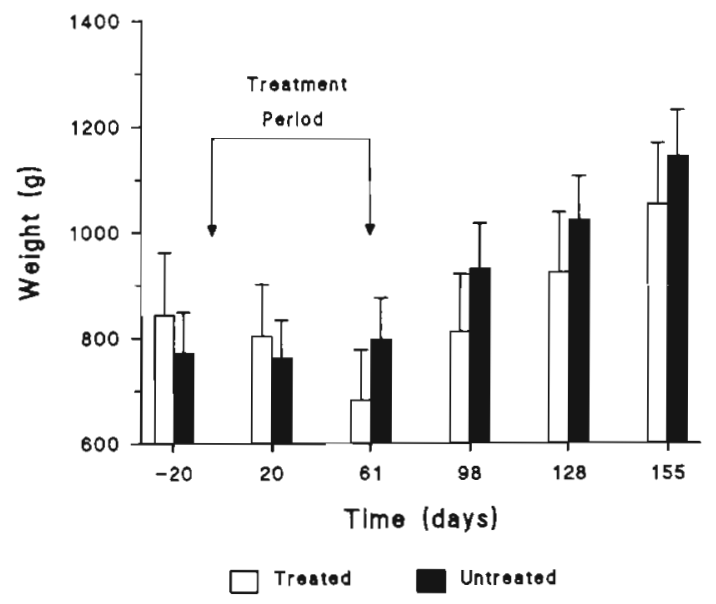

Fig. 3. Dicentrarchus labrax. Comparison of sea bass weight $( \pm 1 \mathrm{SE})$ for treated and control groups in Expt 1
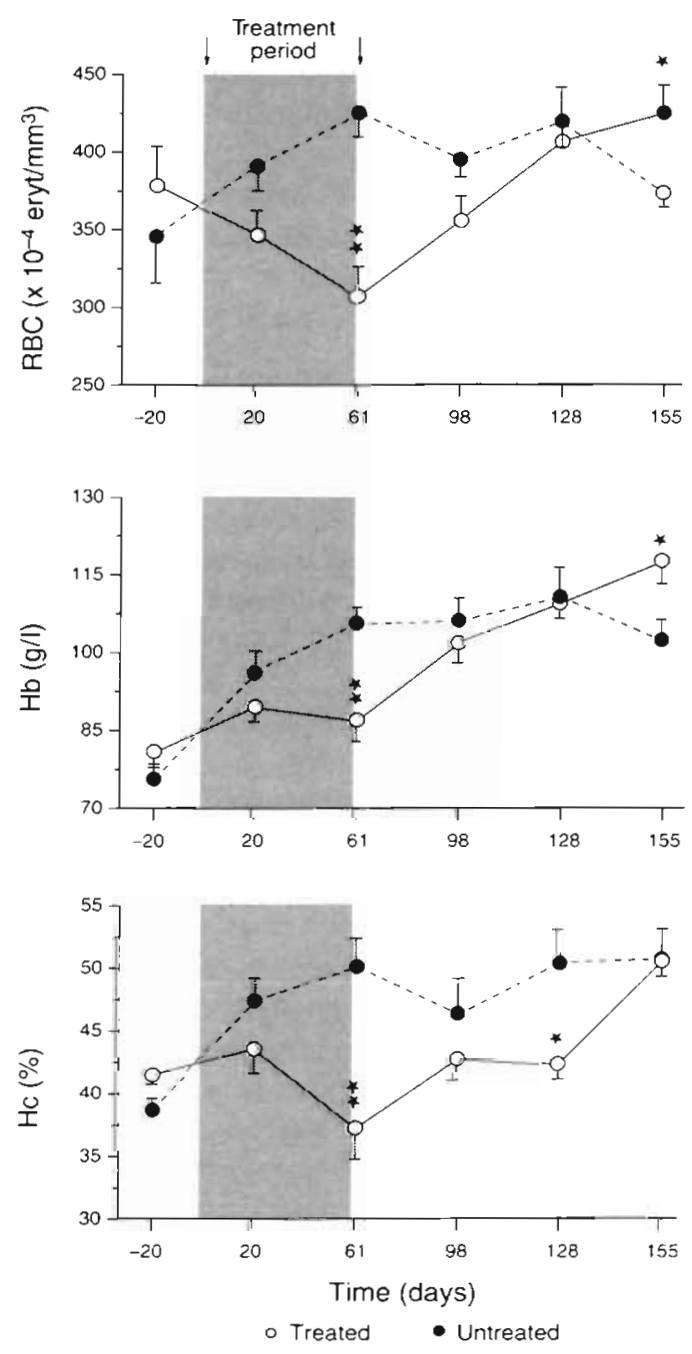

Fig. 4. Dicentrarchus labrax. Comparison of red blood cell count (RBC) haemoglobin (Hb) and hematocrit (HC) $( \pm 1$ SE) for treated and control groups in Expt 1. : p $<0.05 \star \star: p<0.01$
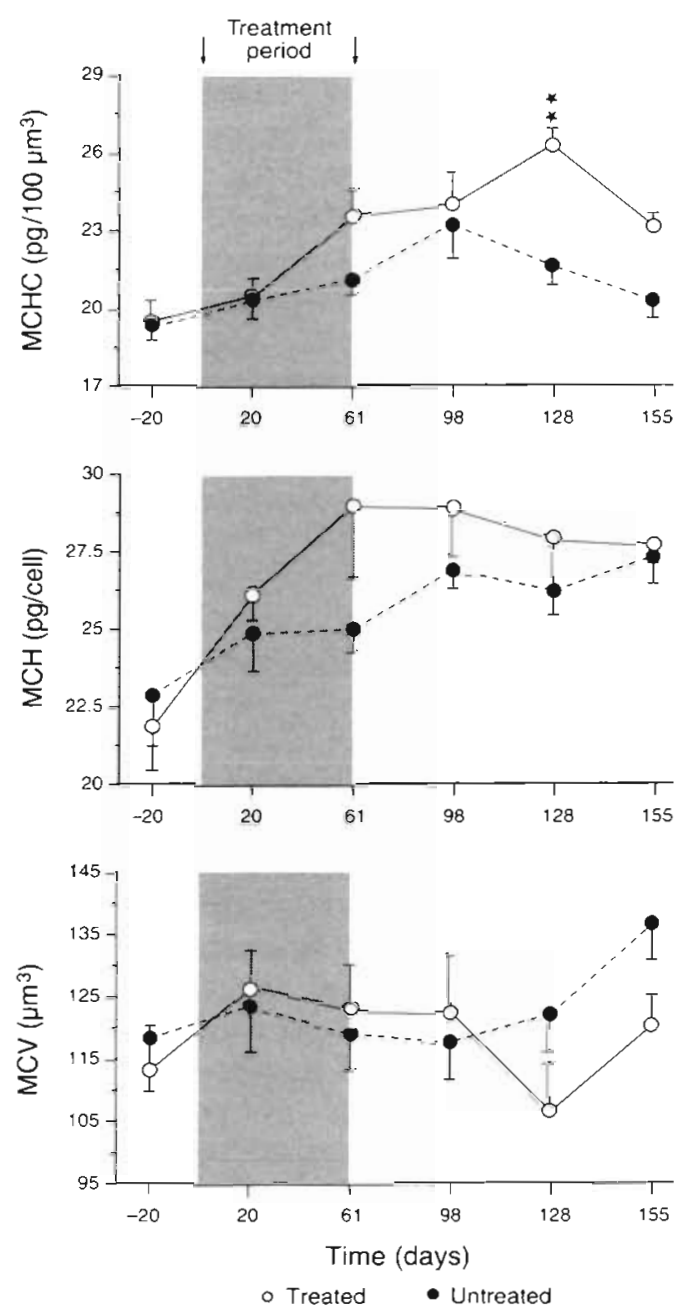

Fig. 5. Dicentrarchus labrax. Comparison of mean corpuscular haemoglobin content $(\mathrm{MCHC})$, mean haemoglobin concentration (MCH) and mean corpuscular volume (MCV) ( $\pm 1 \mathrm{SE}$ ) for treated and control groups in Expt 1. $\star \star: p<0.01$

with spermatozoa (Fig. 2D), whereas testes from untreated males lacked germinative tissue almost completely, and fibrotic granuloma occupied the seminiferous tubules (Fig. 2C).

\section{Toxic effects}

Expt 1

After $8 \mathrm{wk}$ of medication, treated fish showed swimming disorders, loss of appetite and weight (Fig. 3) and statistically significant decreases of $\mathrm{Hb}, \mathrm{Hc}$ and $\mathrm{RBC}$ (Fig. 4). Additionally, treated fish had higher MCHC and $\mathrm{MCH}$ than controls, whereas MCV values of the treated group remained slightly lower but similar to those of the untreated group (Fig. 5). Study of sections from the hematopoietic organs did not reveal any noticeable damage or alteration of white and red cells composition. 
Table 1 Dicentrarchus labrax. Comparison of haemoglobin ( $\mathrm{Hb}$ ), hematocrit $(\mathrm{HC})$ and red biood cell count (RBC) (all $\pm 1 \mathrm{SE}$ ) in Expt 2. C: control group; ST: short treatment group; LT: long treatment group. Different superscripted letters indicate significant differences $(p<0.05)$ between groups on each sampling day

\begin{tabular}{|c|c|c|c|c|}
\hline Sampling day & Type of treatment & $\mathrm{Hb}\left(\mathrm{g}^{-1}\right)$ & $\mathrm{Hc}(\%)$ & $\mathrm{RBC}\left(\times 10^{-4} \mathrm{~mm}^{-3}\right)$ \\
\hline-20 & $\mathrm{C}$ & $97.69 \pm 2.92$ & $50.25 \pm 1.73$ & $348.69 \pm 11.69$ \\
\hline \multirow[t]{3}{*}{15} & $\mathrm{C}$ & $108.86 \pm 2.14^{b}$ & $51.95 \pm 1.23^{\mathrm{ab}}$ & $397.52 \pm 13.84$ \\
\hline & $\mathrm{ST}$ & $98.10 \pm 3.57^{\mathrm{b}}$ & $43.70 \pm 1.10^{b}$ & $370.20 \pm 13.40$ \\
\hline & LT & $130.50 \pm 4.51^{\mathrm{a}}$ & $54.37 \pm 1.60^{a}$ & $402.40 \pm 14.50$ \\
\hline \multirow[t]{3}{*}{35} & $\mathrm{C}$ & $83.05 \pm 2.57$ & $36.58 \pm 1.31^{a b}$ & $355.32 \pm 11.80^{d}$ \\
\hline & $\mathrm{ST}$ & $82.80 \pm 3.70$ & $40.90 \pm 0.06^{\prime h b}$ & $299.30 \pm 13.00^{a b}$ \\
\hline & $\mathrm{LT}$ & $91.70 \pm 5.40$ & $46.00 \pm 0.02^{\mathrm{d}}$ & $339.20 \pm 22.00^{a b}$ \\
\hline \multirow[t]{3}{*}{90} & $\mathrm{C}$ & $98.70 \pm 3.86^{\mathrm{d}}$ & $41.20 \pm 1.13^{\circ}$ & $302.00 \pm 9.86^{\circ}$ \\
\hline & $\mathrm{ST}$ & $84.70 \pm 4.90^{\mathrm{ab}}$ & $38.00 \pm 1.50^{\mathrm{d}}$ & $332.60 \pm 11.66^{\mathrm{a}}$ \\
\hline & LT & $65.70 \pm 4.90^{\mathrm{b}}$ & $29.80 \pm 2.10^{b}$ & $240.10 \pm 19.90^{b}$ \\
\hline
\end{tabular}

Table 2. Dicentrarchus labrax. Comparison of mean corpuscular haemoglobin content (MCHC), mean haemoglobin concentration $(\mathrm{MCH}$ ) and mean corpuscular volume (MCV) (all $\pm 1 \mathrm{SE}$ ) in Expt 2. C: control group; ST: short treatment group; LT: long treatment group. Different superscripted letters indicate significant differences $(p<0.05)$ between groups on each sampling day

\begin{tabular}{|c|c|c|c|c|}
\hline Sampling day & Type of treatment & $\mathrm{MCHC}\left(\mathrm{pg} 100 \mu \mathrm{m}^{-3}\right)$ & $\mathrm{MCH}\left(p g\right.$ cell $\left.^{-1}\right)$ & $\operatorname{MCV}\left(\mu \mathrm{m}^{3}\right)$ \\
\hline-20 & $\mathrm{C}$ & $19.70 \pm 0.76$ & $28.52 \pm 1.38$ & $146.75 \pm 7.53$ \\
\hline \multirow[t]{3}{*}{15} & $\mathrm{C}$ & $21.11 \pm 0.50^{\mathrm{b}}$ & $27.99 \pm 1.01$ & $132.99 \pm 4.34^{\mathrm{clb}}$ \\
\hline & ST & $22.50 \div 0.73^{\text {wh }}$ & $26.71: 1.08$ & $119.43 \pm 4.91^{\mathrm{b}}$ \\
\hline & LT & $23.20 * 3.00^{d}$ & $30.62 \div 2.06$ & $131.97 \pm 8.03^{\circ}$ \\
\hline \multirow[t]{3}{*}{35} & $\mathrm{C}$ & $22.90 \pm 6.60^{\mathrm{a}}$ & $25.02 \pm 0.06$ & $110.09 \pm 3.73^{\circ}$ \\
\hline & sT & $20.20 \pm 2.70^{\text {ah }}$ & $27.63 \div 1.01$ & $136.72 \pm 3.49^{\mathrm{ab}}$ \\
\hline & $\mathrm{LT}$ & $20.00 \pm 6.00^{b}$ & $27.23: 1.01$ & $136.17 \pm 3.09^{a}$ \\
\hline \multirow[t]{3}{*}{90} & $\mathrm{C}$ & $23.90 \pm 0.80$ & $32.90 \pm 1.48^{d}$ & $137.22 \pm 4.21^{\mathrm{a}}$ \\
\hline & ST & $22.30 \pm 0.80$ & $24.58 \pm 1.78^{\circ}$ & $110.61 \pm 7.00^{\mathrm{b}}$ \\
\hline & $\mathrm{LT}$ & $22.00 \pm 0.60$ & $27.78 \pm 1.52^{b}$ & $126.61 \pm 7.15^{\circ}$ \\
\hline
\end{tabular}

Two months following cessation of treatment (Day 128), $\mathrm{Hb}, \mathrm{RBC}$ and $\mathrm{MCH}$ of medicated fish recovered to normal values, though $\mathrm{Hc}$ remained significantly lower than in control fish. Furthermore, MCHC increased significantly in treated fish, while MCV was lower than in controls. Later on (Day 155), a rebound effect was observed in $\mathrm{Hb}$ and $\mathrm{RBC}$, whereas $\mathrm{HC}$, $\mathrm{MCHC}$ and $\mathrm{MCH}$ tended to reach control values.

\section{Expt 2}

In Tables $1 \& 2$, the values of the studied hematological parameters in ST, LT and control groups are expressed. A statistically significant decrease of $\mathrm{Hb}$, Hc and RBC was observed in the LT group at $90 \mathrm{~d}$ postinjection, similar to that observed in Expt 1. Nevertheless, this decrease was lower in the ST group, and without statistical significance.
The histological study did not reveal significant changes in hematopoietic organs of treated fish. Nevertheless, the liver of medicated fish exhibited a certain degree of steatosis at $15 \mathrm{~d}$ post-injection (Fig. 6), which was more evident at Day 35.

\section{DISCUSSION}

The reported results revealed the potential use of Fumagillin against Sphaerospora testicularis. It was shown in Expt 1, by the lower prevalence of infection of treated fish than that of untreated ones in the spawning season following Fumagillin medication, the testicular recovery of some medicated fish and their earlier spermiation time. Fumagillin has been reported to stop sporogenesis of Myxidium giardi from Anguilla anguilla (Székely et al. 1988), S. renicola from Cyprinus carpio (Molnár et al. 1987), PKX 


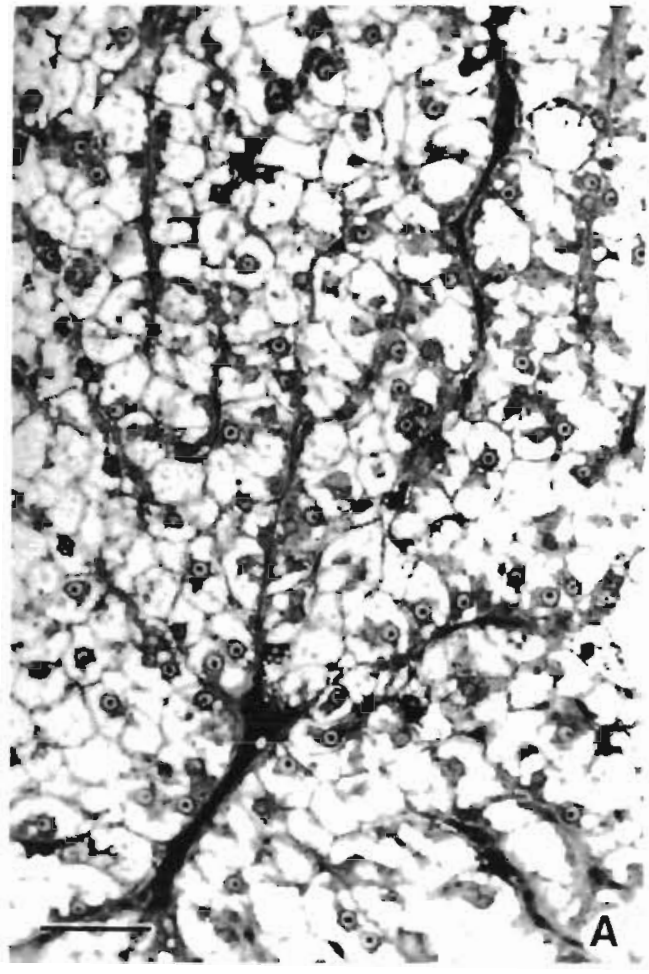

in salmonids (Hedrick et al. 1988), early intracellular trophozoites and more developed plasmodia of Hoferellus carassi (Yokoyama et al. 1990), and Myxobolus cerebralis in rainbow trout (El-Matbouli \& Hoffman 1991)

Nevertheless, our treatment did not appear to be capable of stopping a well established sphaerosporosis with spores and other developmental stages, as the infection persisted in treated fish throughout most of the experimental period, until the following spawning season. The seasonal fluctuations and the testicular damage observed in parasitized fish were similar to those reported previously in other sea bass stocks (Sitjà-Bobadilla \& Alvarez-Pellitero 1990, 1992) The inability of Fumagillin to stop advanced myxosporean infections has been pointed out by other authors (Molnár et al. 1987, Székely et al. 1988), though it might alter spore vlability of Myxobolus cerebralis (El-Matbouli \& Hoffman 1991). On the other hand, the real efficacy of Fumagillin as a preventive treatment of testicular sphaerosporosis remains to be elucidated, due to the lack of an experimental model.

Toxic effects of Fumagillin treatment have been documented by several researchers. Effects ranged from the dizziness and loss of appetite of human patients treated for amebiasis (Killough et al. 1952), to the mortality provoked by an 8 wk dosage of $1.0 \mathrm{~g}$ $\mathrm{kg}^{-1}$ feed in PKD-infected rainbow trout (Hedrick et al. 1988). However, moderate side effects are most commonly reported. Hedrick \& McDowell (1987) and Hedrick et al. (1988) described certain toxicity in chinook salmon Oncorhynchus tshawytscha, experimentally infected by PKX, with a Fumagillin-DCH treatment similar to ours. They also observed a depletion of haematopoietic cells in the kidney interstitium and vacuolation of the epithelium of the renal tubules. In contrast, we did not observe any histopathological sign in hematopoietic tissues of medicated sea bass. A slighter treatment ( 4 wk dosage of $0.01 \%$ applied against chinook salmon experimentally infected by the microsporean Enterocytozoon salmonis, was less toxic but it also induced a decrease of $\mathrm{Hc}$ and haematopoietic renal tissue (Hedrick et al. 1991)

Our treatment assays had toxic side effects, mainly consisting of a decrease in $\mathrm{Hc}, \mathrm{Hb}$ and $\mathrm{RBC}$ values. These decreases were probably due to a destruction of erythrocytes, which provoked the compensatory increase of $\mathrm{MCHC}$ and $\mathrm{MCH}$. In Expt 1, the progressive recovery of haematologic values after the withdrawal of the drug indicates the reversible nature of the toxicity, as it has been reported by other authors (Lauren et al. 1989, Wishkovsky et al. 1990, Hedrick et al. 1991). The slower recovery of the Hc values than those of RBC and $\mathrm{Hb}$ could be explained by the decrease of MCV. However, these blood changes were not correlated with histological anomalies of the haematopoietic tissues in any experiment. In the opinion of Lauren et al. (1989), the decrease in hemato- 
crit combined with hypocellularity of the head kidney and spleen suggests that the treatment induces aplastic anemia.

Steatosis has been described as a physiological process in wild sea bass, and as a consequence of unbalanced artificial diets in cultured fish as well (Lemaire et al. 1991). In Expt 2, the vacuolation of hepatic tissue due to an excessive lipoid storage in treated individuals cannot be attributed to the diet, since untreated fish, fed with the same diet, did not exhibited such a hepatic degeneration. Probably, Fumagillin medication affected lipidic metabolism. Lauren et al. (1989) have also reported hepatic changes (hemorrhages, congestion and focal perisinusoidal extravasation of blood) in rainbow trout injected via aorta with 60 and $30 \mathrm{mg}$ Fumagillin-DCH kg-1 body wt. Nevertheless, hepatic toxicity was not apparent when F-DCH was administered in the diet over a long period of time.

In conclusion, the toxic side effects of this drug seem to depend on the dose and duration of treatment. The efficacy of Fumagillin appears to be related to the degree of establishment of the parasite in the host, at the time of treatment and thus Fumagillin should be considered more as a parasitestatic than as a parasiticide.

Acknowledgements. This work was supported by a grant (FPI) from the Ministerio de Educación y Ciencia of Spain to A.S.-B. and the Project MAR/89/0557 from the Comision Interministerial de Ciencia y Tecnología (CICYT) of Spain.

\section{LITERATURE CITED}

Alderman, D. J. (1986). Whirling disease chemotherapy. Bull Eur. Ass. Fish Path. 6: 38-40

Bailey, L. (1953). Effect of fumagillin upon Nosema apis (Zander). Nature 171: 212-213

El-Matbouli, M., Hoffman, R. W. (1991). Prevention of experimentally induced whirling disease in rainbow trout Oncorhynchus mykiss by Fumagillin. Dis. aquat. Org. 10: $109-113$

Hedrick, R. P., McDowell, T (1987). Fumagillin protects juvenile chinook salmon from experimental infections with PKX, the causative agent of proliferative kidney disease. FHS/AFS Newsletter 15: 7

Hedrick, R. P., Groff, J. M., Baxa, D. V (1991). Experimental infections with Enterocytozoon salmonis Chilmonczyk Cox, Hedrick (Microsporea): an intranuclear microsporidium from chinook salmon Oncorhynchus tshawytscha Dis. aquat. Org. 10: 103-108

Hedrick, R. P., Groff, J. M., Foley, P., McDowell, T (1988) Oral administration of Fumagillin-DCH protects chinook salmon Oncorhynchus tshawytscha from experimentallyinduced proliferative kidney disease. Dis. aquat. Org. 4 $165-168$

Kano, T., Fukui, H. (1982). Studies on Pleistophora infection in eel, Anguilla japonica - I. Experimental induction of microsporidiosis and fumagillin efficacy. Fish Pathol. 16: 193-200
Kano, T., Okauchi, T., Fukui, H. (1982). Studies on Pleistophora infection in eel, Anguilla japonica - II. Preliminary test for application of fumagillin. Fish Pathol. 17: $107-114$

Katznelson, H., Jamieson, C. A. (1952). Control of Nosema disease of honeybees with fumagillin. Sc:ence 115: 70

Killough, J. H., Magill, G.-B., Smith, R. C. (1952). The treatment of amebiasis with fumagillin. Science 115: 71-72

Lauren, D. J., Wishkovsky, A., Groff, J. M, Hedrick, R. P., Hinton, D. E. (1989). Toxicity and pharmacokinetics of the antibiotic fumagillin, in yearling rainbow trout (Salmo gairdneri). Toxicol appl. Pharmacol. 98: 444-453

Lemaire, P., Drai, P., Mathieu, A., Lemaire, S, Carrière, S., Giudicelli, J., Lafaurie, M. (1991). Changes with different diets in plasma enzymes (GOT, GPT, LDH, ALP) and plasma lipids (cholesterol, triglycerides) of sea bass (Dicentrarchus labrax). Aquaculture 93: 63-75

Lewis, L. C., Lynch, R. E. (1970). Treatraent of Ostrinia nubialis larvae with Fumidil B to control infections caused by Perezia pyraustae. J. Invertr. Pathol. :5: 43-48

Liu, T P. (1973). Effects of Fumidil B on the spore of Nosema apis and on lipids of the host cell as revealed by freezeetching. J. Invertr. Pathol. 22: 364-368

Lynch, R. E., Lewis, L. C. (1971). Reoccurrence of the microsporidian Perezia pyraustae in the European corn borer, Ostrinia nubialis, reared on diet containing Fumidil-B. J. Invertr. Pathol. 17: 243-246

McCowen, M. C., Callewder, M. E., Lawlis, J. F. Jr (1951). Fumagillin $\left(\mathrm{H}_{2}\right)$ a new antibiotic with amoebicidal properties. Science 113: 202-203

Mehlhorn, H., Schmahl, G., Haberkorn, A. (1988). Toltrazuril effective against a broad spectrum of protozoan parasites. Parasitol. Res. 75: 64-66

Mills, R. F. N. (1955). The action of fumagillin on a bacteriophage in Staphylococcus aureus. J. gen. Microbiol. 19: $209-240$

Molnár, K., Baska, F., Székely, C. (1987). Fumagillin, an efficacious drug against renal sphaerosporosis of the common carp Cyprinus carpio. Dis. aquat. Org. 2: 187-190

Schmahl, G., Mehlhorn, H., Taraschewski, H. (1989). Treatment of fish parasites. 7. Effects of sym. triazinone (toltrazuril) on developmental stages of Myxobolus sp. Bütschli, 1882 (Myxosporea, Myxozoa): a light and electron microscopic study. Europ. J. Protistol. 25: 26-32

Shadduck, J. A. (1980). Effect of fumagillin on 'in vitro' multiplication of Encephalitozoon cuniculi. J. Protozool. 27: $202-208$

Sitja-Bobadilla, A., Alvarez-Pellitero, P. (199)). Sphaerospora testicularis sp. nov. (Myxosporea: Sphaerosporidae) in wild and cultured sea bass, Dicentrarchus labrax (L.), from the Spanish Mediterranean area. J. Fish Dis. 13: 193-203

Sitjà-Bobadilla, A., Alvarez-Pellitero, P. (1992). Population dynamics of Sphaerospora dicentrarchi Sitja-Bobadilla et Alvarez-Pellitero, 1992 and S. testicularis Sitjà-Bobadilla et Alvarez-Pellitero, 1990 (Myxosporea: Bivalvulida) infections in wild and cultured Mediterranean sea bass (Dicentrarchus labrax L.). Parasitology (in press)

Székely, C., Molnár, K., Baska, F. (1988). Efficacy of fumagillin against Myxidium giardi Cépéde, 1906 infection of the European eel (Anguilla anguilla): new observations on myxidiosis of imported glass eels. Acta Vet. Hung. 36: $239-246$

Takahashi, S., Egusa, S. (1976). Studies on Glugea infection of the ayu, Plecoglossus altivelis, II. On the prevention and treatment. 1. Fumagillin efficacy as a treatment. Jap. J. Fish. 11: 83-88

Wishkovsky, A., Groff, J. M., Lauren, D. J., Toth, R. J. 
Hedrick, R. P. (1990). Efficacy of fumagillin against proliferative kidney disease and its toxic side effects in rainbow trout (Oncorhynchus mykiss) fingerlings. Fish Pathol 25: $141-146$

Responsible Subject Editor. W. Körting, Hannover, Germany
Yokoyama, H. Ogawa, K., Wakabayashı, H. (1990). Chemotherapy with fumagillin and toltrazuril against kidney enlargement disease of coldfish caused by Hoferellus carassi. Fish Pathol. 25: 157-163

Manuscript first received: May 12, 1992

Revised version accepted: August 10.1992 